\title{
VYBRANÉ FAKTORY OVLIVŇUJÍCÍ POJIŠŤOVNICTVÍ S OHLEDEM NA SOUČASNOU EKONOMICKOU SITUACI V ČR I VE SVĚTĚ
}

\section{Petra Růčková ${ }^{1}$}

klíčová slova: pojišstovnictví, finanční krize, ekonomický vývoj, finanční trhy, investice, distribuce, náklady na pojistné plnění

key words: insurance, financial crisis, economic development, financial markets, investment, distribution, insurance benefit

\begin{abstract}
Abstrakt:
Pojišstovnictví patří k oborům podnikání, které se výraznou měrou podepisují na stabilizaci měnové politiky země. Podstata tkví především ve faktu, že podstatná část prostředků akumulovaných v tomto oboru podnikání je investování do dlouhodobých aktiv včetně státních cenných papírů, což stabilizuje pohyb měny v rámci ekonomiky. Navíc tato skutečnost podporuje i reinvestování dočasně volných prostředků, což umožňuje rozvoj ekonomiky. Př́íspěvek si klade za cíl na základě provedené analýzy vyhodnotit základní faktory ovlivňující pojišt'ovnictví v kontextu současného krizového vývoje. Komparace a analýza je zaměřena zejména na vliv ekonomického vývoje na stabilitu pojistného trhu, na vliv finančních trhů, distribuční kanály a jejich roli v dostupnosti pojistných produktů a také na vliv nákladů na pojistná plnění v České republice a v zemích Evropské unie.
\end{abstract}

\begin{abstract}
:
Insurance is one of the fields of business, which are significantly signing of monetary policy to stabilize the country. The essence lies primarily in the fact that a substantial part of the funds accumulated in the field of business is investment in fixed assets, including government securities, which stabilises the currency movement within the economy. In addition, this fact supports the reinvestment of temporarily free resources, allowing the development of the economy. Contribution aims on the basis of this analysis to assess the fundamental factors affecting the insurance industry in the context of the current crisis development. The comparison and analysis focused on the impact of economic development on the stability of the insurance market, the impact of the financial markets, distribution channels and their role in the availability of insurance products and also the influence of claims in the Czech Republic and in the European Union countries.
\end{abstract}

\section{Úvod}

Na základě údajů z Eurostatu klesla ekonomická aktivita v Evropské unii během prvních třech měsíců roku 2009 čtvrtletně o 2,5 \% a meziročně až o 4,6 \%, což výrazně zaostalo za očekáváním úrovně $2 \%$, resp. $4,1 \%$. Z největších ekonomik seskupení klesla mezičtvrtletně ekonomika Německa o 3,8 \%, Itálie o 2,4 \%, Španělska o 1,8 \% a Francie o 1,2 \%. Pokles ekonomiky eurozóny se tak zrychluje, i když za poslední tři měsíce roku 2008 klesl HDP krajin eurozóny mezičtvrtletně o 1,6 \%. Světovým ekonomickým vývojem je samozřjejě ovlivněn také trh pojistný, nicméně vývoj na světovém pojistném trhu i na jednotlivých pojistných trzích je ovlivňován i celou řadou jiných faktorů, které podstatným způsobem

\footnotetext{
${ }^{1}$ This paper ensued thanks to the support of the grant - GAČR 402/08/0067 - Financial Integration of the EU New Member States with Eurozone.
} 
ovlivní jejich pozici v rámci dané ekonomiky. Hlavní faktory jsou znázorněny ve schématu č. 1, nicméně je důležité si uvědomit, že výčet faktorů není úplný. Výběr byl proveden s ohledem na specifikaci cíle příspěvku.

Schéma č. 1: Faktory ovlivňující velikost předepsaného pojistného

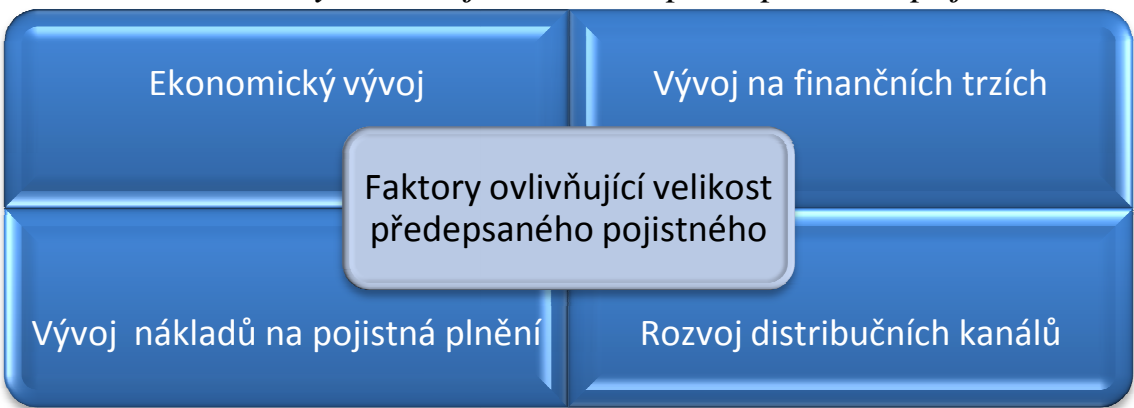

Zdroj: vlastní zpracování

\section{Ekonomický vývoj}

Bezesporu nejdůležitějším faktorem ovlivňujícím vývoj $\mathrm{v}$ předepsaném pojistném $\mathrm{v}$ posledním období se řadí ekonomický vývoj, což je pochopitelné z pohledu možností a potenciálu jednotlivých ekonomických subjektů, které se o zařazení pojištění do svého investičního portfolia budou rozhodovat tehdy, budou-li disponovat dostatečným množstvím finančních prostředků. Předepsané pojistné je ukazatelem hodnocení výkonnosti pojištoven.

Evropa si z hlediska kontextu celosvětového měřítka předepsaného pojistného $\mathrm{v}$ posledních deseti letech upevnila své vedoucí postavení na světových pojistných trzích. V období mezi lety 1985 až 2008 se postupně zvyšovala podíl evropského předepsaného pojistného a v roce 2007 už Evropa vykazovala hodnotu ve výši $43 \%$ na celosvětovém pojistném trhu, zatímco Severní Amerika $33 \%$ a Asie $21 \%$. Tato situace se však mírně změnila v roce 2008 , kdy evropský a americký podíl na předepsaném celosvětovém pojistném snížila expanze na asijských trzích. Asie zvýšila svůj podíl na 22,1\%, Evropa naopak poklesla na úroveň 40,5\%. Nicméně je nutné poznamenat, že oproti Severní Americe jde v Evropě o první pokles podílu předepsaného pojistného po více než 10 letech. Vývoj v jednotlivých letech je uveden rovněž v následujícím grafu.

Graf č. 1: Rozdělení podílů předepsaného pojistného ve světě v letech 1985 až 2008

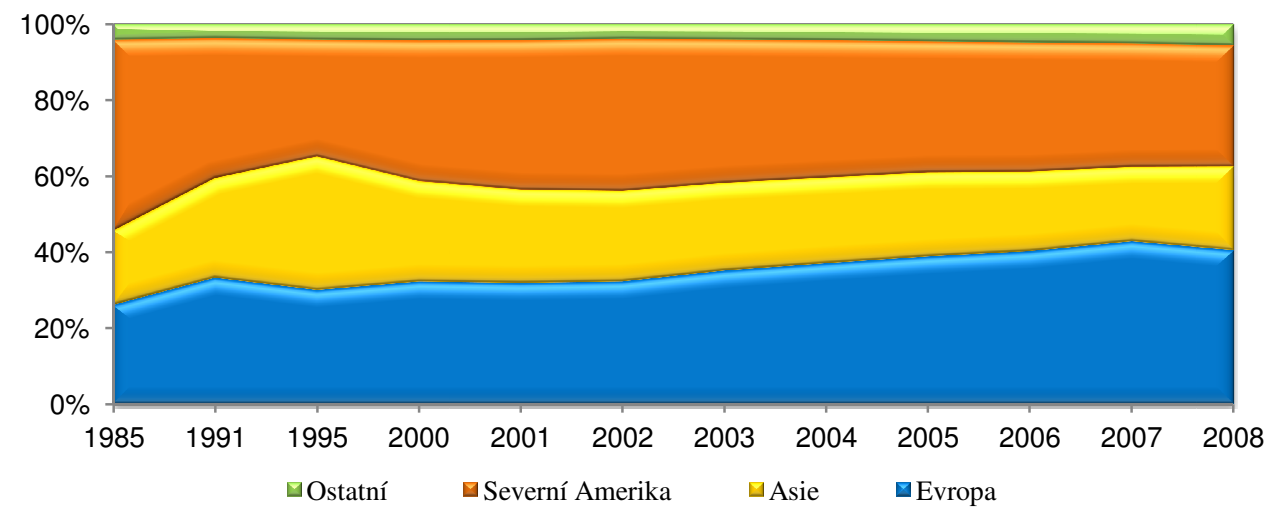

Zdroj: SwissRe - Sigma

Europe $(*)=$ Western and Central / Eastern Europe 
Pokud bychom vyhodnocovali evropský trh jako celek, pak největším počtem pojišstoven disponuje pojistný trh ve Velké Británii, v rámci něhož bylo v roce 2008 registrováno 1096 pojišt'oven. Druhým největším trhem z pohledu počtu pojišt'oven představuje německý pojistný trh s 660 pojišt’ovnami. To jen potvrzuje fakt, že pojišt'ovnictví ve vyspělých zemích je charakteristické vysokým počtem pojišt'oven a tedy i vysokou mírou konkurenčnosti nabídek pojistných produktů. Pojišt'ovnictví ve Velké Británii má dlouholetou historii a je rozhodně více ustálené nežli pojistné trhy v zemích méně vyspělých. Britské pojišstovnictví patři bezesporu mezi největší v Evropě, což lze dokumentovat také například tím, že z hlediska velikosti celkového předepsaného pojistného na evropském pojistném trhu tvoří to britské 31,3\%. Při hodnocení největších evropských pojišt'oven je nutné konstatovat, že v první pětce jsou zastoupeny dvě pojišt'ovny britské, pojišt'ovna italská a francouzská. Ačkoliv tyto pojištovny mají stabilní pozici na evropském pojistném trhu, nevykazují stejné tempo růstu předepsaného pojistného. Výraznější tempo růstu vykázala pouze AXA a dále pojišstovny Prudential. Ke změnám došlo pouze ve druhé polovině spektra první desítky pojišstoven, kde výrazně oslabila svou pozici pojišt'ovna ING, na jejíž úkor si vylepšily svou pozici pojišt'ovny Aegon a Legal \& General. Jedinou německou pojišt'ovnou v první desítce z hlediska velikosti předepsaného pojistného je pojišt'ovna Allianz, nicméně již dlouho si drží své dominantní postavení.

Budeme-li porovnávat počty pojišt'oven ve vyspělých zemích s počty pojištoven působících na trzích zemí Visegrádské čtyřky, rozdíl budeme shledávat markantní. V České republice, Polsku a Mad'arsku převažuje počet neživotních pojišt'oven nad životními, jen na Slovensku tomu bylo od roku 2005 opačně. Nicméně je nutné také poznamenat, že kromě Polska (zde jsou pojišt'ovny započítány do jedné ze dvou kategorií podle podílu na podnikatelské činnosti) vykazují ostatní tři země velmi vysoký podíl smíšených pojištoven. To znamená, že pod hlavičkou jedné pojištovny jsou nabízeny jak produkty životního, tak produkty neživotního pojištění. Pojistný trh v České republice tvořilo k 31. 12. 2009 celkem 35 tuzemských pojišstoven, 16 poboček pojišt'oven ze zemí EU a 1 pobočka pojišt'ovny z třetího státu. Do počtu tuzemských pojišt'oven není zahrnuta Česka kancelář pojistitelů (ČKP) a rovněž VIG RE zajišt'ovna, a.s. Situaci z hlediska struktury pojišt'oven na českém pojistném trhu dokumentuje následující tabulka.

Tabulka č. 1: Struktura pojištoven podle typu podnikání

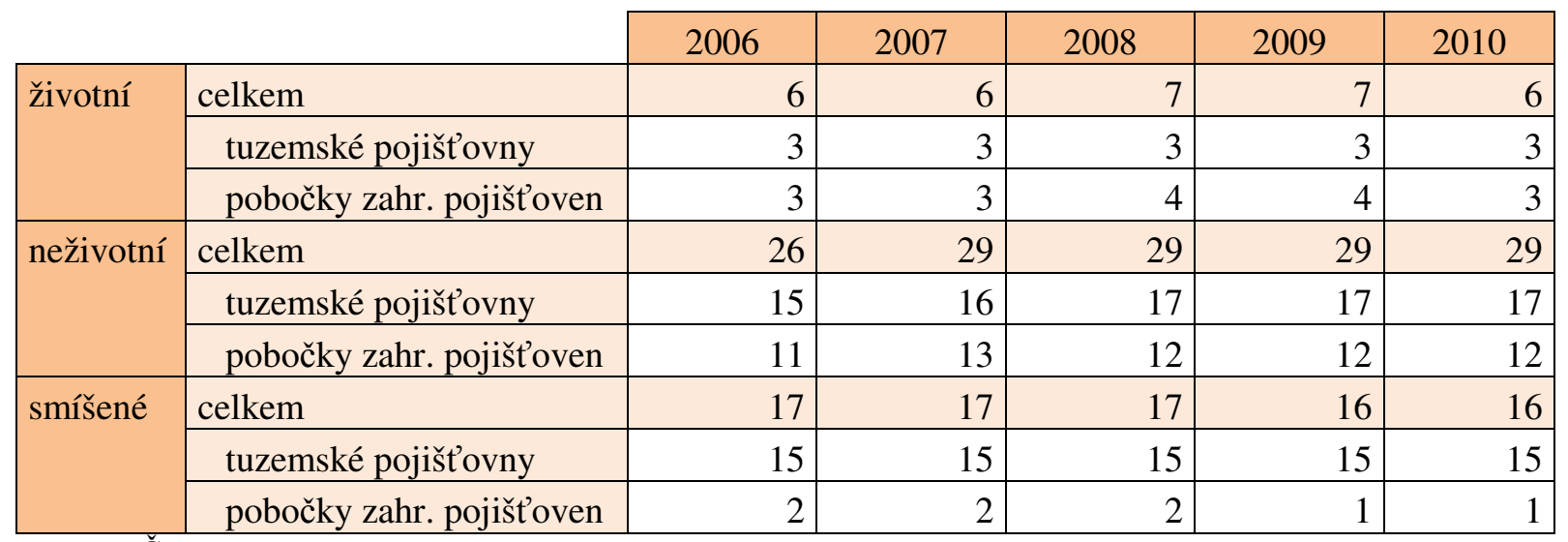

Pramen: ČNB

Z tabulky je na první pohled zřejmé, že struktura pojišt'oven na českém pojistném trhu je do značné míry velmi stabilizována. Je zde zřejmý velmi vysoký podíl smíšených pojištoven, 
což je jev typický pouze pro země východní a střední Evropy, nebot' v souladu se zákonnými ustanoveními již nemohou pojišt'ovny vznikat jako smíšené a musí mít striktně odděleno podnikání v oblasti životního a neživotního pojištění. Na českém trhu dále působí pojišstovny z EU/EHP na základě svobody dočasně poskytovat služby. Ke konci roku 2009 podle údajů ČNB projevilo zájem formou př́íslušné notifikace 614 společností, což je o 60 společností více oproti předchozímu roku. Tyto subjekty se na českém území zaměřují zejména na oblast neživotního pojištění. Aktuální údaje o výkonu těchto pojišt'oven nejsou známy, lze je odhadnout na jednotky miliard korun. ${ }^{2}$ Tabulka č. 2 dokumentuje vývoj předepsaného pojistného a nákladů na pojistná plnění na českém pojistném trhu.

Tabulka č. 2: Vývoj predepsaného pojistného a nákladů na pojistná plnění na českém pojistném trhu

\begin{tabular}{|l|l|r|r|r|r|}
\cline { 3 - 6 } \multicolumn{2}{l|}{ životní } & 2006 & 2007 & 2008 & 2009 \\
\hline \multirow{3}{*}{ neživotní } & $\begin{array}{l}\text { Předepsané pojistné, očištěné od } \\
\text { zajištění }\end{array}$ & 45918356 & 52757195 & 55447565 & 58725330 \\
\cline { 2 - 6 } & Hrubá výše nákladů na pojistná plnění & 18836983 & 25195222 & 30576022 & 33400171 \\
\cline { 2 - 6 } & zajúténí pojistné, očištěné od & 51059109 & 56628444 & 59284827 & 61216371 \\
\hline
\end{tabular}

Pramen: ČNB

Z tabulky je patrné, že je možné zaznamenat ve všech sledovaných letech nárůst objemu předepsaného pojistného, nicméně oproti roku 2007 s již menší dynamikou. Navíc je potřeba také poznamenat, že náklady na pojistná plnění rostou rychleji, než velikost předepsaného pojistného. Tato situace může zkomplikovat pozici pojištoven (viz níže).

\section{Vývoj na finančních trzích}

Dalším faktorem je vývoj na finančních trzích, který ovlivňuje zejména oblast životního pojištění, které své volné technické rezervy umist'uje zejména do aktiv na finančních trzích. Neschopnost nebo omezená schopnost zhodnocovat takto svěřené prostředky omezí i ochotu pojišt'ovat se. Podle Petra Vinše je současná krize do značné míry nestandardní. Zvláštností je, že v dřívějších obdobích začínala krize v hospodářském sektoru a v současnosti začíná v sektoru finančním. Efekt na hospodářský sektor je tak sekundární. Pojišt’ovnictví však není typickým reprezentantem krizové vývoje, nebot' krize se zde projevila prozatím pouze zpomalením, resp. stagnací tempa růstu. $\mathrm{Na}$ začátku roku 2009 nebyla predikce vývoje pojistného trhu př́liš příznivá. Nakonec se však pesimistické prognózy nenaplnily. Světový pojistný trh sice zaznamenal výraznou stagnaci, nicméně odborníci poznamenávají, že tato situace se více méně odvíjí od faktu, že pojištovny jsou součástí velkých finančních konglomerátů. To je například důvod finančních problémů jedné z nejvýznamnějších mezinárodních pojišt'ovacích organizací American International Group, Inc. (AIG). Ta mimo jiné pojištovala problémové úvěrové instrumenty a obchodovala s finančními deriváty, které jsou využívány například k zajištění rizik. AIG je rovněž hlavním upisovatelem takzvaných „credit-default swaps“, tedy pojistek proti bankrotu firem, které vydávaly dluhopisy a jiné cenné papíry. Loňský vývoj českého pojistného trhu sice proti roku 2008 zaznamenal zhruba poloviční růst, přesto zásadně nepodlehl vlivům hospodářské krize. Celkový objem předepsaného pojistného vzrostl meziročně o 2,5\% na téměř 140 miliard korun zejména díky životnímu pojištění. Tempo růstu životního pojištění se meziročně zvýšilo o výrazných 5,1\%,

\footnotetext{
${ }^{2}$ Zpráva o výkonu dohledu nad finančním trhem, str. 102
} 
u neživotního pojištění statistiky zaznamenaly téměř stagnaci $(+0,6 \%){ }^{3}$ Dle Singera prošel český pojistný trh krizí téměř nedotčen, nebot' pojišt'ovny na našem pojistném trhu realizují investice na základě konzervativních investičních strategií.

Finanční krizí jsou však ovlivněny kromě finančních konglomerátů také pojišstovny fungující podle tradičního modelu. Kromě pojištovací činnosti vystupuje každá pojišt’ovna jako významný institucionální investor, který investuje rezervy pojistného na kapitálovém trhu a je tak ovlivněn jeho aktuální situací. Pokud pojištovna investovala do společností zasažených krizí či cenných papírů vydaných těmito společnostmi, musí odepsat podstatnou část hodnoty této investice. Obtížné podmínky na trhu potvrzuje jednička na evropském pojišt’ovacím trhu, německá pojišt'ovna Allianz. Ve druhém čtvrtletí klesl její čistý zisk o $28 \%$ na 1,5 mld. EUR. A vedení pojišt'ovny neočekává, že by se její situace mohla ještě v průběhu letošního roku výrazně zlepšit. Hlavním důvodem tohoto poklesu je vysoká provozní ztráta dceřiné společnosti Dresdner Bank. Kromě bankovního sektoru se finanční krize dotkla především životního a zdravotního pojištění. Z hlediska výčtu pojišt'oven postižených krizí je dalším př́́kladem pojišt'ovna Aegon, která má určitou úvěrovou expozici vůči Lehman Brothers, přičemž objem této rizikové expozice činí teoreticky maximálně 265 milionů eur. Velikost ztrát v poměru k celkovému kapitálu není významná. Krizi však pocítí i klienti, kterým bude připsáno nižší zhodnocení, ačkoliv investiční portfolio nezaznamenalo významnější změnu. Průměrný stav na evropském pojistném trhu v roce 2008 dokumentuje graf č. 2 . V případě investičního pojištění již došlo k výraznému poklesu hodnoty smluv. Vzhledem k tomu, že na rozdíl od penzijních fondů nemají pojišt’ovny povinnost rozdělovat zisk, lze očekávat, že si z prrípadného zisku budou chtít letos pojišt’ovny ukrojit na úkor klientů větší část.

Graf č. 2: Struktura investičního portfolia na evropském pojistném trhu v roce 2008

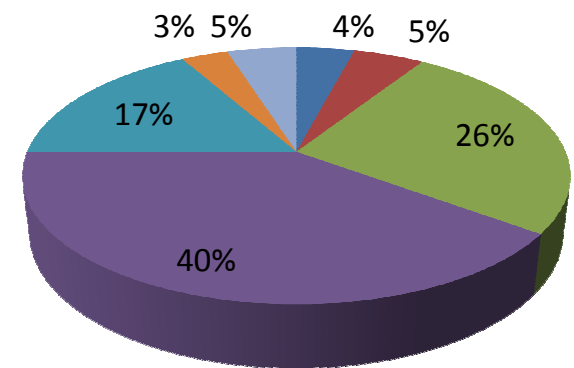

Nemovitosti
Akcie a podíly
Půjčky včetně hypotéčních
Ostatní investice

- Investice v dceřinných společnostech

Obligace

Depozita

Pramen: Server CEA [on-line] URL: http://www.cea.eu/index.php?page=statistics [staženo 20. 9. 2010]

V České republice na straně aktiv vzrostly investice do dluhových i majetkových cenných papírů s různým potenciálem výnosu a stupněm rizika. Struktura investičního portfolia v roce 2009 je zřejmá z grafu č. 3. K růstu pasiv došlo zejména v důsledku vyšší tvorby technických

\footnotetext{
3 Lesk a bída pojistného trhu. Server Jsme partners [on-line] URL: http://www.jsmepartners.cz/vmediich/343/lesk-a-bida-pojistneho-trhu [staženo 20. 9. 2010]
} 
rezerv. Budeme-li vyhodnocovat investiční portfolio z pohledu současné finanční krize, pak je s ohledem na striktně definovanou strukturu investic bude velmi pravděpodobně vliv minimální. U státních dluhopisů se dá očekávat snižování jejich cen, což ale primárně neovlivní výnosnost investice. Zásadnějším problémem by mohl být pouze pokles zájmu o investiční životní pojištění, resp. životního pojištění obecně. Vše je do značné míry závislé na tom, jak je propracován systém sociálního pojištění na úrovni státu. Čím menší míru zabezpečení nabídne, tím pravděpodobněji nebude vliv krize př́liš podstatný. Země Visegradské čtyřky však mají velmi dobrou úroveň sociální pojištění na úrovni státu, takže se krize může projevit omezením zájmu o životní, i neživotní pojištění, nebot' zvýšení nákladů na běžné fungování se zpravidla projeví v ochotě uzavírat nákladné pojistky. V tuto chvíli je potřeba si také uvědomit, že s finanční krizí souvisí také možnost investování s důrazem na diverzifikaci rizika. Ačkoliv pojištovnictví disponuje značným množstvím finančních prostředků plynoucího z dlouhodobého životního pojištění, finanční krizí se omezil počet titulů, do kterých mohou pojišt'ovny relativně bezpečně a relativně výnosně investovat své technické rezervy.

Graf č. 3: Struktura investičního portfolia pojištoven na českém pojistném trhu v roce 2009

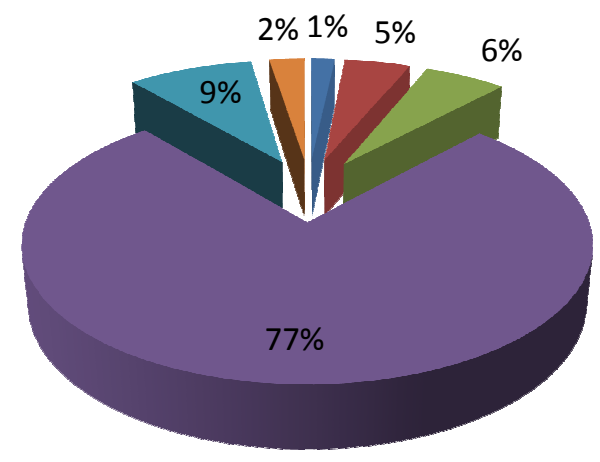

- Nemovitosti $\square$ Majetkové účasti $\square$ Akcie a podíly $\square$ Dluhopisy $\square$ Depozita $\square$ Ostatní investice

Pramen: Výroční zpráva ČAP, www.cap.cz [staženo 20. 9. 2010]

\section{Náklady na pojistná plnění}

Neméně významným faktorem je vývoj nákladů na pojistná plnění s ohledem na výskyt katastrof. Tento faktor se zdá být důležitý zejména sohledem na skutečnost, že při přetrvávající finanční krizi je velmi pravděpodobný dopad jak na obyvatelstvo, tak i na efektivní fungování firem. Zpravidla první nákladovou položkou, která je určena k redukci, bývá použito zrušení pojištění, resp. jeho omezení na nezbytně nutné minimum. Navíc stále častěji se v posledních letech analyzují dopady klimatických změn na přijetí živelního katastrofického rizika do pojištění. Z hlediska informací plynoucích z výročních zpráv Evropského výboru pojistitelů je možné konstatovat, že škodovost v oblasti neživotního pojištění velmi výrazně roste. Zajišt'ovna Munich Re uveřejnila studii, z které vyplývá, že se největší měrou na nákladech na pojistná plnění podílejí vichřice a bleskové povodně, třetí nejvyšší náklady jsou vykazovány $\mathrm{v}$ důsledku tropických cyklónů. V České republice „pojišstovny vyplatily za toto období více než 90 miliard korun na úhradu škod, které způsobily živelní pohromy na majetku jejich klientů. Nejrozsáhlejší škody způsobily povodně. $\mathrm{V}$ jejich důsledku nahlásili klienti pojišt'ovnám téměř 280 tisíc pojistných událostí v celkové hodnotě 53 miliardy korun. 240 tisíc pojistných událostí bylo nahlášeno v souvislosti s vichřicí a krupobitím, které způsobily škody ve výši 8,5 miliardy korun. 
Sněhová nadílka na střechách pak představuje z pohledu pojišt’oven 88 tisíc nahlášených škod v celkové výši 2,9 miliardy korun. Jen letošní živelní pohromy způsobily škody, které pojišt'ovny odhadují na 9,5 miliardy korun. “4 Ve výčtu největších živelních katastrof v České republice figuruje od roku 2000 čtyřikrát povodeň a dvakrát vichřice. Největší škody napáchala povodeň v srpnu 2002, kdy bylo na pojistném plnění vyplaceno více než 34 miliard Kč.

\section{Distribuční kanály jako potenciál expanze}

Velmi výrazným faktorem potenciální expanze pojistných trhů je nalezení vhodných distribučních kanálů. Způsob distribuce je důležitý pro obě strany uzavírané smlouvy. Pojišt'ovna hledá co nejrychlejší a co nejefektivnější př́ístup ke klientovi, klient naopak hledá optimalizaci svého pojistného a investičního portfolia a minimalizaci nákladů na pořízení pojištění. V tomto ohledu se situace začala v posledním desetiletí měnit, proto byl pro názornost zvolen komparační pohled let 2001 a 2008. Situaci je tedy možné dokumentovat na vývoji distribučních kanálů uvedených v následující tabulce, kde rok 2001 představuje rok výchozí a rok 2008 představuje poslední dostupnou hodnotu z Evropského výboru pojistitelů.

Tabulka č. 3: Komparace způsobů distribuce pojistných produktů ve vybraných zemích v letech 2001 a 2008

\begin{tabular}{|l|c|c|c|c|c|c|c|c|c|c|}
\hline & \multicolumn{7}{|c|}{$\mathbf{2 0 0 1}$} & \multicolumn{1}{|c|}{$\mathbf{2 0 0 8}$} \\
\cline { 2 - 12 } & $\begin{array}{l}\text { Př́mý } \\
\text { prodej }\end{array}$ & Agenti & Brokeři & Bankopojištění & Ostatní & $\begin{array}{c}\text { Př́mý } \\
\text { prodej }\end{array}$ & Agenti & Brokeři & Bankopojištění & Ostatní \\
\hline Rakousko & $30,6 \%$ & $5,4 \%$ & $20,0 \%$ & $39,5 \%$ & $4,5 \%$ & $25,9 \%$ & $9,2 \%$ & $24,0 \%$ & $36,7 \%$ & $4,1 \%$ \\
\hline Belgie & $16,6 \%$ & $8,4 \%$ & $44,1 \%$ & $30,2 \%$ & $0,7 \%$ & $19,6 \%$ & $6,6 \%$ & $43,0 \%$ & $30,2 \%$ & $0,6 \%$ \\
\hline Bulharsko & $0,0 \%$ & $0,0 \%$ & $0,0 \%$ & $0,0 \%$ & $0,0 \%$ & $21,4 \%$ & $41,2 \%$ & $37,4 \%$ & $0,0 \%$ & $0,0 \%$ \\
\hline Španělsko & $0,0 \%$ & $41,0 \%$ & $29,0 \%$ & $10,0 \%$ & $20,0 \%$ & $15,1 \%$ & $27,7 \%$ & $18,2 \%$ & $37,3 \%$ & $1,7 \%$ \\
\hline Francie & $23,0 \%$ & $16,0 \%$ & $12,0 \%$ & $44,0 \%$ & $5,0 \%$ & $22,0 \%$ & $16,0 \%$ & $15,0 \%$ & $45,0 \%$ & $2,0 \%$ \\
\hline Velká Británie & $23,5 \%$ & $4,6 \%$ & $63,2 \%$ & $2,4 \%$ & $6,6 \%$ & $11,0 \%$ & $16,4 \%$ & $63,2 \%$ & $4,8 \%$ & $4,6 \%$ \\
\hline Itálie & $7,3 \%$ & $44,9 \%$ & $3,4 \%$ & $44,3 \%$ & $0,0 \%$ & $10,0 \%$ & $48,1 \%$ & $4,0 \%$ & $38,0 \%$ & $0,0 \%$ \\
\hline Holandsko & $24,0 \%$ & $50,0 \%$ & $0,0 \%$ & $15,0 \%$ & $11,0 \%$ & $41,4 \%$ & $46,5 \%$ & $0,0 \%$ & $10,7 \%$ & $1,3 \%$ \\
\hline Polsko & $28,5 \%$ & $57,1 \%$ & $14,3 \%$ & $0,0 \%$ & $28,6 \%$ & $23,5 \%$ & $38,5 \%$ & $7,2 \%$ & $29,9 \%$ & $0,9 \%$ \\
\hline Portugalsko & $7,8 \%$ & $31,6 \%$ & $7,9 \%$ & $50,1 \%$ & $2,6 \%$ & $7,4 \%$ & $24,4 \%$ & $5,6 \%$ & $61,8 \%$ & $0,8 \%$ \\
\hline Slovinsko & $62,0 \%$ & $27,0 \%$ & $1,0 \%$ & $10,0 \%$ & $0,0 \%$ & $13,6 \%$ & $62,8 \%$ & $13,3 \%$ & $2,3 \%$ & $8,0 \%$ \\
\hline Slovensko & $25,3 \%$ & $62,4 \%$ & $12,3 \%$ & n/a & $0,0 \%$ & $63,9 \%$ & $34,0 \%$ & $0,2 \%$ & $0,0 \%$ & $1,9 \%$ \\
\hline Turecko & $20,4 \%$ & $65,6 \%$ & $4,7 \%$ & $9,3 \%$ & $0,0 \%$ & $8,5 \%$ & $65,0 \%$ & $9,2 \%$ & $17,4 \%$ & $0,0 \%$ \\
\hline Pram
\end{tabular}

Pramen: Statistické informace CEA. Server CEA - Evropské asociace pojistitelů [on-line] URL: http://www.cea.eu/index.php?page=statistics [staženo 20. 9. 2010]

V mnoha sledovaných zemích Evropské unie je patrný odklon distribuce pojištění prostřednictvím obchodníků coby zaměstnanců pojišt’oven. Distribuční kanály se podle statistických údajů začaly postupně měnit. Je možné zaznamenat odklon od přímého prodeje a vázaných pojišt'ovacích zprostředkovatelů (agenti) a př́klon $\mathrm{k}$ pojišt’ovacím zprostředkovatelům (brokeři), kteří pracují ve prospěch klienta, což může pro klienta znamenat optimalizaci pojistného portfolia. Lze však říci, že tento vývoj byl postupný a pravděpodobně nemá přímou souvislost s probíhající krizí. Naopak například na Slovensku se přímý prodej stal výrazně dominantní s podílem $64 \%$. Nicméně tato situace je, jak je patrné z tabulky pouze ojedinělá. Silnou pozici u zprostředkovatelů vykazuje Itálie a u brokerů je

\footnotetext{
${ }^{4}$ Pramen: Tisková zpráva České asociace pojistitelů, Nedávejte živlům šanci.
} 
tradičně vysoký podíl u Velké Británie a Belgie. Velmi výraznou pozici zejména ve vyspělých zemích si v posledních desetiletích vybudovala distribuční sít' prostřednictvím bankovních poboček. Je to důsledek rozvoje bankopojištění. Významnou pozici má bankopojištění ve Francii, co je ovšem pochopitelné, nebot' Francie bývá považována za kolébku vzniku této formy distribuce. Překvapivý nárůst zaznamenalo Portugalsko a Španělsko. Jsou však také země, které zaznamenaly pokles zájmu, jako například Itálie a Rakousko. Zajímavá situaci je možno sledovat na polském pojistném trhu, kde ještě v roce 2001 byl podíl bankopojištění naprosto nevýznamný, zatímco v roce 2008 byl již podíl téměř $30 \%$. Důvodem využívání této formy distribuce je pravděpodobně snaha o snížení nákladů v důsledku provázanosti finančního trhu a existence velkých finančních skupin z hlediska vlastnické struktury. Podle zprávy Ministerstva financí České republiky byly distribuční kanály na českém pojistném trhu rozděleny ve čtvrtém čtvrtletí roku 2009 následovně.

\section{Tabulka č. 4: Distribuční kanály v pojišt'ovnictví}

\begin{tabular}{|l|c|c|}
\hline & životní & neživotní \\
\hline externí distribuce (tzv. neovládaní PA, PM a jejich VZ) & $40 \%$ & $46 \%$ \\
\hline $\begin{array}{l}\text { interní distribuce (vlastní VZ, ovládaní PA a PM, jejich VZ, přepážkový prodej } \\
\text { zaměstnanci pojišt'oven) }\end{array}$ & $37 \%$ & $45 \%$ \\
\hline bankopojištění & $20 \%$ & $5 \%$ \\
\hline ostatní (pošta, cestovní kanceláře, apod.) & $3 \%$ & $1 \%$ \\
\hline dálkový prodej (on-line internetový, telefonický) & $0 \%$ & $3 \%$ \\
\hline
\end{tabular}

Pramen: Ministerstvo financí ČR

Vzhledem k tomu, že sledování způsobů distribuce není primárně předmětem zájmu ani dozorového ani dohledového orgánu, nelze vytvořit pro Českou republiku objektivní časovou řadu tohoto rozložení. Nad rámec základního členění na externí a interní distribuci je samostatně sledována kategorie bankopojištění představující prodej pojištění bankami jak ze stejné, tak i jiné finanční skupiny, jako je daná pojišt'ovna. Tento kanál lze vnímat jako rozhraní mezi interní a externí distribucí. Př́́kladem praktického uplatňování bankopojišt'ovnictví v České republice může být ING ČR, která kromě banky a pojišt'ovny zahrnuje další typy finančních institucí. Pojišstovny vlastněné Českou spořitelnou a Komerční bankou nesou ve svých názvech jména svých mateřských společností a mohou proto těžit ze společného marketingu, což představuje další výhodu vedle rozsáhlých pobočkových sítí těchto bank. V podobně výhodné situaci se nalézá také ČSOB pojišt'ovna. ${ }^{5}$ Lze konstatovat, že na externí formě prodeje jsou ve větší či menší míre závislé všechny pojišt'ovny $s$ výjimkou dvou největších pojištoven. ${ }^{6}$

\section{Závěr}

V rámci příspěvku byly vyhodnocovány čtyři vybrané faktory, které ovlivňují velikost předepsaného pojistného. Celková situace na pojistných trzích sice zatím nepotvrdila obavy, které plynuly $\mathrm{z}$ dopadů finanční krize, nicméně je potřeba si uvědomit, že krize se v plné míre projeví až $\mathrm{v}$ datech pozdějších. Na základě provedené analýzy výsledků pojištoven ve vybraných zemích Evropské unie je možné konstatovat, že jako největší problém se v tuto chvíli jeví nestabilita na finančních trzích. Existuje zejména strach z nedostatečného

\footnotetext{
${ }^{5}$ Davidová, P., Jirka, J. Bankopojištění v ČR nepatř́i jen do oblasti teorie. Server ČNB [online] Url: http://www.cnb.cz/cs/verejnost/pro_media/clanky_rozhovory/media_2004/cl_04_040617a.html [staženo 10.9.2010]

${ }^{6}$ Analýza vybraných aspektů distribuce na finančním trhu v ČR. Server MF ČR [online] Url: http://www.mfcr.cz/cps/rde/xbcr/mfcr/Analyza_vybranych_aspektu_distibuce_na_FT_CR_-_MFCR_2009.pdf [staženo 10.9.2010]
} 
zhodnocování pojistných rezerv, nebot' velký podíl v investicích představují státní cenné papíry, u nichž se dá prredpokládat menší míra zhodnocení, v řadě zemí se krize projevila také nedostatečnou tvorbou hrubého domácího produktu. Naplní-li se tato skutečnost, pak lze očekávat, že se to projeví ve skupině ukazatelů, které vyhodnocují rozdělení trhu mezi jednotlivé podnikatelské subjekty. To dokládají také výsledky největších evropských pojistitelů. Šance na řešení potenciálních problémů je v zefektivnění distribučních sítí pojistných produktů. V tomto ohledu došlo v mnoha zemích ke změně, resp. reorganizaci distribuce. Situaci v tuto chvíli navíc komplikuje skutečnost, že velmi výrazným způsobem narůstá škodovost $\mathrm{v}$ oblasti neživotního pojištění $\mathrm{v}$ důsledku přírodních katastrof ${ }^{7}$.

\section{Literatura}

[1] DAVIDOVÁ, P., JIRKA, J. Bankopojištění v ČR nepatř́ jen do oblasti teorie. Server $\check{C} N B$ [online] Url: http://www.cnb.cz/cs/verejnost/pro_media/clanky_rozhovory/media_2004/cl_04_040617 a.html [staženo 10.9.2010]

[2] RƯČKOVÁ, P. Vybrané aspekty bankopojištovnictví In KULHÁNEK, L., POLOUČEK, S. (Red.): Finance v pedagogické a védeckovýzkumné činnosti (II). Sborník referátů z mezinárodního semináře kateder financí. Karviná: OPF SU, 2000. Str. 146-153. ISBN 80-7248-058-8.

[3] RƯČKOVÁ, P. Bankopojišt’ovnictví v Evropě a v České republice. In. Finanční ř́zení podniků a finančních institucí 2005.

[4] Analýza vybraných aspektů distribuce na finančním trhu v ČR. Server MF ČR [online] Url:

http://www.mfcr.cz/cps/rde/xbcr/mfcr/Analyza_vybranych_aspektu_distibuce_na_FT_C R_-_MFCR_2009.pdf [staženo 10.9.2010]

[5] Lesk a bída pojistného trhu. Server Jsme partners [on-line] URL: http://www.jsmepartners.cz/v-mediich/343/lesk-a-bida-pojistneho-trhu [staženo 20. 9. 2010]

[6] Tisková zpráva České asociace pojistitelů, Nedávejte živliom šanci. Server ČAP. [online] Url: www.cap.cz [staženo 10.9.2010]

[7] Server CEA [on-line] URL: http://www.cea.eu/index.php?page=statistics [staženo 20. 9. 2010]

[8] Zpráva o výkonu dohledu nad finančním trhem. Server ČNB [on-line] URL: www.cnb.cz [staženo 10.9.2010]

Klasifikace JEL: G15, G22

Ing. Petra Růčková, Ph.D.

Obchodně podnikatelská fakulta v Karviné

Slezská univerzita v Opavě

Univerzitní nám. 1934, 73340 Karviná

ruckova.petra@seznam.cz

\footnotetext{
${ }^{7}$ Tisková zpráva České asociace pojistitelů, Nedávejte živlům šanci. Server ČAP. [online] Url: www.cap.cz [staženo 10.9.2010]
} 